演題376は,上腕に挙上制限のある患者のための肘関節 撮影用補助台の試作である，时関節に限らず，正碓な整 位を行なうために患者に苦痛を与えることは少なくない。 ペーシェントケアが言われている今日, 放射線技師にと ってこの種の研究は大切なことであろう。

以上 4 題は，いずれも現場で直面する問題について， 自分で解決しようという努力の成果であり, 確実に仕事 の品質を一歩前進させたものと思う。

，私は他施設を見学させて貪う機会があるとき，最新鋭 の機器もさることながら, そこで使われている撮影補助 具に大きな関心がある.メーカーのカタログではなかな か得られない創意工夫が発見できるからである。これに より，その施設の技師の仕事に対する姿勢までが分かる ような気がする。

\section{MR-11 臨床応用（演題番号377～383）}

松村義光（獨協医科大学病院）

本セッションは臨床応用をテーマとし 7 題の予定であ ったが，383席の演者が急病のため取り消しがあった。

演題377は 3 次救急での MRI 検査の有効性を述べた もので非磁性の人工呼吸器を MR 室へ持ち込み, 勤務時 間内に救急の時間枠を設け有効に活用している.

質問（倉持 帝京市原病院，前田 恒生病院）意識 のない患者の場合どのように対処しているか.

答：検査中は医師が検查室内に入り監視している。

質問 (座長) 3 次救急のオーダーは多いか.

答、オーダーは多く、ニーズに答えるのが難しい. 勤 務時間内で対応時間帯を設定してあるが，17時から19時 位までの時間外についても検討している.

演題378は消化管領域に MRI を利用したもので進行 癌の深達度を手術前に胃の全体像として知ろうとするも のであった.

質問（藤田 大阪医大）予稿集では水を飲ませて行 っていたが，発表では発泡剈を使用していたが・..また， 水と空気では磁化率の違いによりローデンシティバンド の出方が変わると思うが。

答 実際は発泡剤を使用し，げっぷを出してしまう患 者の場合水を飲ませた。低信号帯として出る病巣部分の 違いには差がなく，診断には支障がない。

質問（座長) 低信号帯が漿膜であるとする根拠は.

答 全摘出した胃を生食に漬けて水とサラダオイルを 混ぜ実験した結果，同様に描出した。

質問（森 富山医科楽科大） 体位を変えての検討は。 答，部位によって違いがあるが，小さい病巣はコロナ
ルで出ない場合があり，コロナルとアキシャルの 2 方向 撮像としておりどちらかで出ている。

質問（前田: 恒生病院）フェーズ方向とエンコード 方向を変えることによる違いはどうか.

答 折り返しが入るため検討していない.

質問 （座長） 超音波内視鏡が盛んだと思うがこれと の対比は。

答 超音波内視鏡は部分描出であるが, MRI では全体 像の中に深達度も描出できる.

演題379は，下垂体後葉を明膫に得るために, MRI の特 性であるケミカルシフトをうまく応用するために周波数 エンコード方向を変化させ検討したもので, その有用性 とその規格化について述べた．規格化という意味におい て，装置の違いにより折り返しの問題やバンド幅の違い による描出の変化が考えられ，今後の更なる調査・研究 を期待したい!

質問 (座長) メーカーの違いあるいは磁場強度の違 いによる差についてはどうか.

答 メ一カーにより差があることを経験している，ま た磁場強度に比例すると思うが，比較の経験はない。 演題380は肝臓領域に改良 Dixon 法を瀶床応用し; 最 適撮像パラメーターを検討し好結果を得たとするもので あった.アーチファクトを減ずる為に ECG 同期併用が 良いとのことであった。

質問（座長）体動のある部位であり, 計算画像に 水・脂肪それぞれが分離できず，混じった画像になった 経験はないか.

答，計算領域が大きいと計算誤差が生じる，そのため できるたけ小さい領域を選択し画像作成している。

演題381は拡散強調画像のシーケンスを用いて錐体路 等の神経路を描出したものであった。実際の臨床応用と 言う意味では今後, 更に臨床の効用としての症例, 有効 症例を提示していただきたい.

質問 （座長） 微細なモーションに弱いと思うがどう 対処しているか.

答 エアーバッグで固定している.

質問 一連の検查の中でこの検查をいれた場合トータ ル時間はどれくらいか.

答 Fast SEを使用しているのでT2・T1強調画像と いっしょに撮像しても30分以内でできている.

演題382 は前回の第 1 報で生じた問題を克服するもの であったが，もう少し明確な臨床症例の提示がほしかう た.

質問 (座長) 動脈瘤が実際に視交叉を圧迫した画像 
の提示がなかったが.

答 2 名あったが画像が良くないため出せなかった。 最後に感想を述べたい：MRの特性（特質）をうまく 応用したまさしく臨床応用と言う報告が多かった。今後 も不得意とされている問題を逆手にとり更に臨床応用と して発展させたものを期待したい.

MR-12 造影剤（演題番号384～389）

川末健作 (Hospi-net)

このセッションでは造影剤に関する発表 4 題, 信号強 度検傠の発表 1 題, 検査手法 1 題であり，どの施設でも 応用可能な発表である.

演題384；臨床で経験する䆏胞状腫瘤の信号強度につ いて実験的に解明しようとの試みで，蛋白含有量と粘土 及び信号強度の関係についてファントム実験を行い，そ の結果を臨床に応用し内容物の性状が推測できるように なったと発表した。

質問 一大阪医科大，滕田一液体の温度測定方法は。 粘土の測定方法, 単位をもう少し検討されてはどうか.

答 50 度高めより始め終了時50度より下がっている. 粘土の変化で大きく影響を受けるのは $\mathrm{T} 2$ 強調画像と しているが，T2が液体の粘土にほほ比例するのは定説で ある. 内容物の性状を推測という試みであるが, 多くの 症例数と推測した結果の比較検討が必要かつ重要と考え る. 症例数を増やし再度報告していただきたい。

演題385; 骨髄疾患における Gd-DTPAを使用したと きの撮像法で dynamic MRI，SE 法 (Gd-DTPA 投与前 後), Dixon 法などについて検討した発表である.いずれ の方法でもそれぞれの特徵があり，SE 法の不足すると ころを病体を考慮にいれながら他の方法を追加ずること になる。

演題386；骨盤腔の検査で腸管の重なりをなくすのに 空気注入法について検討し，小病変の描出能向上に有用 であり，小骨盤腔では矢状断層が有効であると発表した。

質問 一岡山光生病院, 小野一腸管の動きによる影響 はどうか. 対象年龄は．抗コリン剤等の前処置は.

答 骨盤部であるので診断に影響をおよぼすほどでは ない.75才位まで可能. 前処置は特に行っていない.

腸管壁を伸展させる方法として，高信号か低信号か 2 通り考えられる.今回の発表は空気注入により低信号(無 信号）を用いている。過去の発表で高濃度バリウムの発 表もあるが，好置としては空気の方が容易であると思わ れる。

演題387, 388 ；ブルーベリージュースを用いた経口造
影剤の開発に関する基礎研究と臨床応用でオリジナリテ イの高い発表である。

質問 一岡山光生病院，小野ーマンガン濃度の調整方 法は。果汁のマンガン濃度は時季, 樹木などで変動する のでは.

答 果汁の濃度を調製. 製法によっても濃度はことな るが，マンガン濃度の測定を行うことで安定した造影効 果が得られる。

味, 飲みやすさ, 安全性, 造影効果などで優れた造影 剂と思われる.特に造影効果でT1強調画像で陽性, T2強 調画像で陰性造影剤として使用可能である点は，これま での造影剤にはない優れた効果である。今後の開発の成 果を期待したい。

演題389；経口造影剤（OMR）と Ensure Liquid を比 較検討し, Ensure の問題点として信号強度, 副作用等が あり撮像条件，製剤の改良の必要性に言及した。

\section{X線検査- 7 血管造影検査法 (演題番号390～393)}

山 哲男 (関西医科大学附属病院)

この演題群の発表要旨は揭載の抄録の通りである.ま た，会場での一般会員よりの質疑は無かった。. 以下各演 題に対する座長よりの質問および，コメントを記す。 《390席に対して》

質問 回転立体造影を臨床に応用した時の臨床的な意 義は発表された通りと考えるが，この回転立体造影法を 行なうにあたって放射線技術的な問題点は何か.

答，回転立体撮影という性質上，ハレーションの事が 問題になる。特に今回, 食道静脈瘤硬化療法の為に用い たので, 胃を空気で膨らます必要が有り，よりハレーシ ヨンが生じやすくなるので，ハレーションが生ずる部位 にメタリックフィルタを加えてハレーションの防止を行 なっている。

《391席に対して》

質問 装置の構造上，当然正側共撮影距離は同じと考 えてよいのか？

答 医師よりの要望より, 正面はコンタクト撮影で, 撮影距離 $90 \mathrm{~cm}$ ，側面は1.95倍の拡大撮影を行なってい る.

《392席に対するコメント》

論旨として，診断・治療という面が前面に出ている発 表内容ですがもう少し放射線技術的な面を論旨として発 表して頂きたかった. 確かに, interventional なことが高 度に発達発展を遂げてきている昨今，コ・メディカルの 一員である放射線技術者も疾病に対する診断法や治療法 